Tér és Társadalom 17. évf. 2003/3. 115-127. p.

Tér és Társadalom

XVII. évf. 2003 a: 115-127

\title{
KITEKINTÓ
}

\section{A SVÉDORSZÁGI KALMAR MEGYE TERÜLETI INTÉZMÉNYRENDSZERÉNEK ÉS REGIONALIZÁLÓDÁSÁNAK ELEMZÉSE}

\author{
(The Analysis of Regional Institutional System and Its \\ Regionalisation Process of Kalmar County in Sweden) \\ BALOGH ZOLTÁN
}

\begin{abstract}
„A demokratikus intézmények fejlesztése a megye fejlódéséért"

Kulcsszavak:

Svédország Kalmarmegye EU-csatlakozás regionalizálódás területi intézményrendszer megyerégió modell

A közép-európai országok - köztük Magyarország - Európai Unióhoz való csatlakozása és a gazdasági szerkezetváltás által felerösödött területi egyenlötlenségek a regionális politika és az ehhez kapcsolódó intézményrendszer kialakítását teszik szuilkségessé. Mindehhez nélkülözhetetlen olyan országok modelljeinek elemzése a hatékony struktúra kialakítása érdekében, amelyek ugyanezen folyamaton mentek keresz. tül. E tanulmány Svédország tapasztalatainak összegzését kívánja bemutatni a történelmi elözményektöl az elmúlt évek regionalizálódasi kisérletein keresztül a modell magyarországi alkalmazási lehetỏségéig középpontba helyezve Kalmar megye számos tanulsag gal szolgáló regionalizálódását.
\end{abstract}

\section{Bevezetés}

Svédország 1995. január 1-jével az Európai Unió tagjává vált. Az ezt megelőző években az EU egyik törekvésének, a „Régiók Európájának” szellemében már jelentős tudományos viták folytak arról, hogy Svédország milyen útra lép a regionalizmus tekintetében.

Az áttörést az 1997-es esztendő hozta meg. Ekkor fogadták el három Pilot Project keretében Skane, Kalmar és Gotland regionális kísérletét, melyekhez 1999-ben negyedikként csatlakozott Nyugat-Svédország regionális kísérlete is. Ezek közül a Kalmar régió kísérletével kapcsolatban sikerült személyes tapasztalatokra is szert tennem egy tanulmányút során 2002 őszén. Összefoglaló tanulmányom e kísérlet jellemzését és eredményeinek értékelését foglalja magában.

\section{Közigazgatási hagyományok ${ }^{l}$}

Hazánkhoz hasonlóan Svédország hagyományos közigazgatási struktúrával rendelkezik. A földrajzi és éghajlati adottságok miatt sohasem volt jellemző a szétszabdalt települési struktúra. A vidéki és városi térségek önkormányzatiságáról már 
a 14. századtól törvény rendelkezett személyi és pénzügyi tekintetben, de a nemesi hatalom megerősödése miatt csak XI. Károly területi reformja során valósult meg mindez a nemesi földek felosztásával.

Teljes körü önkormányzati szabályozásra a 19. századi társadalmi és politikai változásokat követóen került sor. A nemesi parlamentet ekkor váltotta fel a kétkamarás parlament, az ipari forradalom gazdasági fejlődést eredményezett, és a népességszám is növekedett. Az 1862-es helyi önkormányzati reform elkülönítette az egyházi és a szekularizált területeket. Már ekkor létrehozták a széles körü hatalommal bíró megyei önkormányzatokat (landsting), melyek közvetett képviselöt választhattak a parlament első kamarájába. A pénzügyi hátteret a saját adókhoz való jog biztosította, melynek megállapítására saját hatáskörben a költségvetés elfogadásakor került sor. Ez a rendszer 1970-ig, az egykamarás parlament felállításáig fennmaradt!

A fennálló rendszer 2400 vidéki önkormányzatot, 90 várost és tíz vidék és város közti átmeneti területet foglalt magába (köping). Területi szinten az igazgatás a 25 ezer fő feletti városok kivételével mindenkire vonatkozott.

A modern Svédország kialakulásának folyamatában a városiasodás a vidéki önkormányzatok gazdasági súlyát lecsökkentette, melynek következtében azok megoldhatatlan szociális problémákkal néztek szembe. 1952-re valósult meg a helyi önkormányzatok (kommuner) reformja, melynek keretében 3 ezer föben határozták meg a helyi önkormányzatok lakosságának minimumát. Ez számuk 2282-röl 816-ra való csökkentését eredményezte, átlagos népességük 1500-ról 4500 före növekedett. Mindemellett megszüntek az egyházi közigazgatási határok.

A további népességvándorlás eredményeként további 350 település került a minimum népességszám alá, melynek 2000 före való csökkentése sem volt hatékony. Egy gyenge parlamenti többségủ döntés eredményeként 1974. január 1-ig közigazgatási reformot kellett végrehajtani, melynek során a minimum 8000 fö lett, összevonásra kerültek a vidéki, átmeneti és városi önkormányzatok. Ennek eredménye 278 önkormányzat lett, számukat 282-ben maximálták. Az 1. táblázatban összefoglalva láthatjuk a fenti folyamatot a számok tükrében:

\section{TÁBLÁZAT}

A svéd önkormányzatok száma, 1862-1992

(The Number of Local Governments in Sweden, 1862-1992)

\begin{tabular}{ccccc}
\hline$\dot{E} v$ & Vidéki & Átmeneti & Városi & Összesen \\
\hline 1862 & 2400 & 10 & 90 & 2500 \\
1901 & 2384 & 20 & 92 & 2496 \\
1941 & 2353 & 53 & 117 & 2523 \\
1951 & 2281 & 84 & 133 & 2498 \\
1952 & 816 & 88 & 133 & 1037 \\
1964 & 777 & 96 & 133 & 1006 \\
1969 & 625 & 91 & 132 & 848 \\
1971 & - & - & - & 464 \\
1974 & - & - & - & 278 \\
1992 & - & - & - & 286 \\
$2001^{*}$ & - & - & - & 289 \\
\hline
\end{tabular}

Forrás: Kayfetz et al 1993, 14; * Regional and Local ... 2001, 219. 
A területi közigazgatást tekintve Svédország az egyszintủ modellt követi ${ }^{2}$. A megyék tekintetében (lan) a 24 állami területi egység és 23 önkormányzati egység kialakulása az 1862-es reformokra nyúlik vissza. Svédország 1995-ös Európai Unióhoz való csatlakozása után megindult regionális folyamatok miatt számuk az elmúlt években 18-ra csökkent és mellettük megjelent 3 közigazgatási(!) régió (Skane, Nyugat-Svédország, Kalmar). A területi igazgatást mintegy 70 állami szakhivatal teszi teljessé.

A megyei (és regionális) önkormányzatok (landsting) az egészségügyben és oktatásban játszanak kiemelkedő szerepet, de emellett más feladatokat is ellátnak. Meghatározó bevételi forrásaik az adók, illetve kisebb részben az állami támogatások.

Megyei közigazgatási hivatalok (lansstyrrelsene) feladata a területi tervezés, koordináció, a helyi önkormányzatok felügyelete, illetve a különbözó állami hatóságok koordinációja. Fontos feladatuk, hogy jelenleg ezen megyei közigazgatási hivatalok, a lansstyrrelsenek kezelik a területfejlesztéshez, az agrártámogatásokhoz, a természeti és kulturális örökséghez kötődő európai uniós és állami támogatási forrásokat!

A területi állami hatóságok az építésügyi, mezógazdasági, iskolaủgyi, munkaügyi igazgatásban vesznek részt a területì egységeknek alárendelve.

A csatlakozásig eltelt idỏ alatt egy állandó területi struktúrát, illetve ezzel párhuzamban a települési struktúra szétaprózottságát felszámoló összevonási folyamatokat figyelhetünk meg. Ez a települési hagyományokkal szakító, pusztán a feladatellátási képességre koncentráló önkormányzati egységesülési folyamat biztosítja a magas fokú települési szolgáltatásokat és a lehetőséget arra, hogy a regionális szinten is ( 8 statisztikai régiót figyelembe véve) mindössze $30-35$ település területi egységbe szervezése közigazgatásilag is megvalósuljon. Szemben például Magyarországgal, ahol egy ilyen folyamat legfóbb akadályozója a megyénkénti(!) kb. 160 település, melyek önállóságán még a körjegyzői rendszerek, a közös iskolafenntartás bevezetése sem lazított.

\section{Regionalizálódás a svéd gyakorlatban}

Svédország 1995-ös csatlakozásával a fenti, Magyarországhoz hasonló területi közigazgatási hagyományokkal a következỏ struktúrát alakította ki az EU alapok fogadására (2. táblázat):

2. TÁBLÁZAT

Svédország és Magyarország területbeosztása a NUTS-rendszerben (Regional Division of Sweden and Hungary in the NUTS System)

\begin{tabular}{lccccccccccc}
\hline & \multicolumn{2}{c}{ NUTS 1 } & \multicolumn{2}{c}{ NUTS 2 } & \multicolumn{2}{c}{ NUTS 3 } & \multicolumn{2}{c}{ NUTS 4 } & \multicolumn{2}{c}{ NUTS 5 } \\
\hline $\begin{array}{l}\text { Or- } \\
\text { szág }\end{array}$ & $\begin{array}{c}\text { Terü- } \\
\text { let }\end{array}$ & Száma & $\begin{array}{c}\text { Terü- } \\
\text { let }\end{array}$ & Száma & $\begin{array}{c}\text { Terü- } \\
\text { let }\end{array}$ & Száma & $\begin{array}{c}\text { Terü- } \\
\text { let }\end{array}$ & $\begin{array}{c}\text { Szá- } \\
\text { ma }\end{array}$ & $\begin{array}{c}\text { Terủ- } \\
\text { let }\end{array}$ & Száma \\
\hline $\begin{array}{l}\text { Svéd- } \\
\text { ország }\end{array}$ & Ország & 1 & $\begin{array}{c}\text { Riksom } \\
\text {-raden }\end{array}$ & 8 & Lan & 21 & - & - & $\begin{array}{c}\text { Kom- } \\
\text { muner }\end{array}$ & 289 \\
\hline $\begin{array}{l}\text { Ma- } \\
\text { gyar- } \\
\text { o. }\end{array}$ & Ország & 1 & Régió & 7 & $\begin{array}{c}\text { Megye, } \\
\text { fóváros }\end{array}$ & $19+1$ & $\begin{array}{c}\text { Kís- } \\
\text { térség }\end{array}$ & 150 & $\begin{array}{c}\text { Tele- } \\
\text { pủlés }\end{array}$ & 3135 \\
\hline
\end{tabular}

Forrás: Regional and Local ... 2001, 219.; FVM; Hajdú 2001, 281. 
Nyolc statisztikai régió alakult meg, melyek az EU NUTS 2 szintjének megfelelő statisztikai számbavételnek és a támogatási alapokhoz való hozzáféréshez teremtették meg az alapot. Alapvető közigazgatási átalakulásra nem került sor, közigazgatási jogosítványok átadása csak kísérleti régiók keretében valósult meg.

A magyar viták alapját képező közigazgatási regionalizálódás kérdéséhez a 2002-ig tartó svéd kísérletek nyújthatnak segítséget ${ }^{3}$ :

- A Malmö Önkormányzatot, a Malmöhus és Kristianstad lant magában foglaló Skane régióban, illetve az Alvsborg és Skaraborg lanból alakult NyugatSvédország régióban közvetlenül választottak regionális önkormányzatokat. Ez az ún. szupermegye modell. Lényege, hogy megszúnt a három-három jogelöd megyei önkormányzat és megyei közigazgatási hivatalok, helyüket egyegy regionális önkormányzat és regionális kôzigazgatási hivatal vette át. A megyemodellhez képest megváltozott az irányított terület és lakosság nagysága, ám az alapvető szervezetek, ha új határok között is, de ugyanazon feladatokat látták el. Így a regionális önkormányzat továbbra is elsősorban szolgáltató jellegủ maradt a jóléti állam meghatározó területein (oktatás, egészségügy, szociális ellátás), de új elemként a megyei/regionális közigazgatási hivatalok területfejlesztési feladatával bỏvült ki feladatköre.

- Egy másik irányú kísérlet a Kalmar régióban valósult meg. Itt a megye területén lévő helyi önkormányzatokból és a megyei önkormányzatból alakult régióban közvetetten, a megyei önkormányzatok regionális önkormányzatokat választottak, melyek a területfejlesztési feladatokért felelösek. Ez az ún. megye-régió modell. A következőkben e modellt részletesebben mutatom be.

- Gotland Balti-tengeri sziget mindig is sajátos pozícióban volt a svéd területi igazgatásban, itt ugyanis a helyi és megyei önkormányzati szint ötvöződött, a regionalizálódás során pedig speciális régióként jelent meg, ahol mindkettő funkcióinak ötvözésére került sor. Erre speciális volta miatt a továbbiakban nem térek ki.

Látható, hogy valódi választott régiók kerültek kialakításra, a direkt és indirekt regionális közigazgatás-szervezés irányába egyaránt, a választott képviselőkkel adva identitást az új egységeknek. Megjelenésük egy olyan országban, amely gazdaságilag a legfejlettebbek kỏzül való, és mint fentebb láttuk, ha csak települési szinten is, de képes nagy horderejủ önkormányzati reformok megvalósítására, több mint figyelemreméltó.

A reformmal szembeni kísérleti szakasz oka elsősorban a teruileti igazgatás hagyománya, de véleményem szerint az is, hogy a területi igazgatásban nem merultek fel olyan ellátási feszültségek, mint annak idején a települési önkormányzatoknál. Így átalakítási kényszer nem volt, a közigazgatási reformok megvalósítását csak a tapasztalatszerzést követöen kívánják megvalósítani akkor, ha eredményesebben múködtethetô a feladatellátási rendszer a regionális kísérletek valamelyik típusában.

Fontos e ponton megjegyezni, hogy a magyar viták politikai vitái helyett itt feladatközpontú kísérletről beszélhetünk. Ez alapvetően ellentétes szemléletbeli különbség 
a kérdés eldöntésekor, és jól alkalmazkodik ahhoz a nemzeti jogosultsághoz, hogy az EU-val szemben a közigazgatási és területfejlesztési rendszer átalakítására semmiféle kötelezettség nincs.

\section{A Kalmar régió gazdasági-társadalmi helyzete}

Kalmar megye Svédország délkeleti részén, a Balti-tenger partján húzódik. A déli területek egyik legelmaradottabb megyéje, melynek oka elsősorban nehézkes vasúti és közúti megközelíthetősége. Üveg- és faipara nemzetgazdaságilag is meghatározó, Kelet-Svédország turisztikai központja Stockholm mellett, mely elsősorban kedvezö éghajlatának és tengerpartjai népszerüségének köszönhető.

A múltban meghatározó katonai feladatokat látott el. Stratégiai jelentőségét jelzi, hogy a középkorban Svédország kulcsának nevezték („Kalmar Nyckel”), erödje fennhatóságának megszerzése a Svéd Királyság belsö területeinek megszerzését biztosította. Fontos momentum volt a Kalmari Unió megkötése erödjében, mely a svéd és dán hatalmat egyesítette.

Mára kikötöjét és gazdasági jelentőségét is elvesztette. Stratégiai programjaik ezen történelmi nagyság revitalizálását célozzák meg, de immáron egészen új irányokban. Az új gazdaság hívószavát figyelembe véve Kalmar jövőjét a design, a turizmus, az informatika és az oktatás-kutatás központjaként képzelik el, tudatosan építve a meglévő erőforrásokra (1. üvegipar - design, tengerpart - turizmus, oktatáskutatás - Kalmar Egyetem) és a megye lakóinak lokálpatriotizmusára.

\section{A Kalmar kísérlet tartalma}

A fenti stratégiai célok megvalósításának egyik fontos eszköze egy megfelelö intézményi struktúra kialakítása volt, melynek feladata a programok kidolgozására és folyamatos múködtetésére irányult. Ennek végső formáját egy erős megyei lobbi eredményeként a svéd parlament, a Riksdag is elfogadta és az 1997-es Pilot Projectek keretében Kalmar regionális kísérletének is szabad utat engedett. Mindez annak ellenére történt, hogy a másik két kísérlet Malmö és Göteborg irányításával Svédország két meghatározó gazdasági régióját hozta létre, míg Kalmar megye alapvetően egy átlagos svéd megyének tekinthető.

A Kalmar régió ún. „megye-régióvá” alakult. Ez annyit jelent, hogy határváltozás nélkül, a meglévő megyei határokon belül, egy alulról építkezö regionális intézményt hoztak létre, melynek elnevezése Kalmar Regionförbundet, azaz Kalmari Regionális Tanács.

A hivatalos megfogalmazás szerint: „A Regionális Tanács egy koordinációs testület a helyi és megyei önkormányzatok közti együttmüködésben, amely nagyon hasonló a helyi önkormányzatok hagyományos szövetségéhez. Célja, hogy nagyobb hatékonyságot biztositson, fokozza a források felhasználását, illetve, hogy nagyobb és szélesebb helyi beleszólâst biztositson a megye fejlesztésébe." (The Regional Council... 1997, 2) 


\section{A kalmari kisérlethez vezetö út}

„A jóléti rendszer gyors átalakulása, Európa új térképe, Svédország európai uniós tagsága, a munkanélküliség magas aránya és az információs technológia robbanásszerü fejlödése azok a föbb tényezők, amelyek szükségessé teszik új modellek keresését a modern társadalomban jelentkező problémák megoldása érdekében." (The Regional Council... 1997, 3)

A Kalmari Regionális Tanács ismertetöjének eme kezdömondata összefoglalja mindazon mozgatóeróket, amelyek a kalmari kísérlethez vezettek. Mindezt kiegészítik azok az alapelvek, amelyek szerint a döntéseket a valósághoz lehetö legközelebb kell meghozni, felhasználva a helyi és regionális (megyei) tudást, így érvényre juttatva az EU regionális politikájának decentralizációs és szubszidiaritási alapelveit. A svéd regionális politika korábbi kísérletei azt igazolták továbbá, hogy a régióknak (megyéknek) speciális adottságaikon és a lakosok támogatásán kell alapulniuk.

Ezeket az alapelveket kell figyelembe venni abban a folyamatban, ami az állami kontroll (a megyei közigazgatási hivatalok által) alatt tartott, állami hivatalnokok által irányított regionális fejlesztést egy, a választott képviselők által alkotott testiilet hatáskörébe helyezi át.

\section{A Tanács létrejötte, választások, szervezeti felépitése}

Kalmar megye 1997. július 1-tỏl tért át az új modellre a fenti elvek figyelembevételével az 1996/97. évi 36. Kormányhatározat alapján. Míg a hasonló időszakban megvalósuló más projektek (1997: Skane, 1999: Nyugat-Svédország) a megyék összevonásán alapultak állami döntés következtében, és szupermegyék, valódi régiók kialakítását célozták meg, addig a kalmari lobbi egy teljesen más szempontú modellt vitt keresztül a törvényhozáson.

A modell a megyehatárok fenntartása mellett egy közvetett úton választott testület, amit a megye területén található, közvetlenül választott helyi és megyei önkormányzatok képviselői választanak tagjaik sorából.

Létrehozásának alapvetöen két indoka volt:

- Kiemelje és így súlyt adjon a korábban a területi hivatal hatáskörébe tartozó területfejlesztési feladatoknak a területi közigazgatási struktúrában.

- A területfejlesztés stratégiaalkotási funkciója megköveteli egy olyan szervezet létrehozatalát, amely nem a már meglévő szolgáltatás-orientált szervek hierarchizált szervezeti felépítését követi, hanem egy team-munkára építő rugalmas szervezetet jelent.

Mindennek eredményeként új területi szerv jött létre a megyei önkormányzat és a területi hivatal mellett. Felmerül, hogy ez a struktúra nem eredményez-e hatékonyságvesztést? A válasz erre a fenti definícióból adódik, amely a Regionális Tanácsot a települési szơvetséghez hasonlítja. Ez mutatja, hogy a gyakorlatban nem egy újabb közjogi testület jön létre, sokkal inkább egy koordinatív szerv a helyi és megyei önkormányzatok között, mely a decentralizáció szellemében feladatai többsé- 
gét a megyei közigazgatási hivataloktól veszi át (1. később részletesen). Ezt a funkciót csak legitimálja a kormányrendelet, így elméletileg egy harmadik kőzjogi megyei testület jön létre, de ezen jogszabály csak az identitást biztosítja azáltal, hogy ha csak közvetett úton is, de állampolgári felhatalmazást ad a Regionális Tanácsnak. Ezt jól mutatja az 1. ábra:

\section{1. ÁBRA}

A Regionális Tanács helye a megyei és a helyi önkormányzatok mellett (The Place of the Regional Council beside the Local Governments in County and Settlement Level)

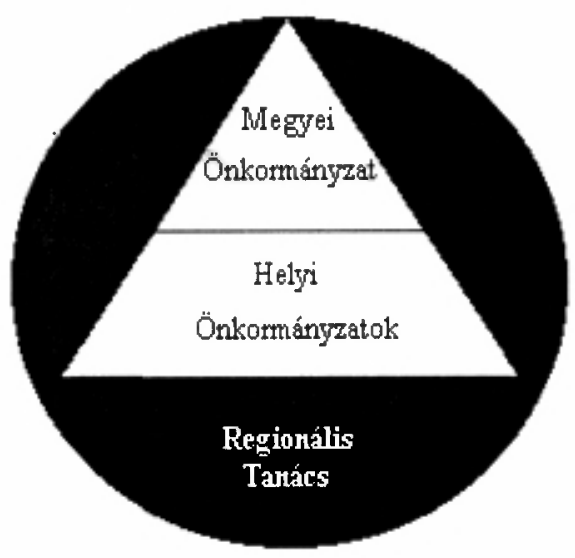

Forrás: Saját szerkesztés.

Az eredeti, 1997-es modell háromszintủ testületet hozott létre: a 45 tagú legfőbb döntéshozó testületet, a Közgyülést (30 helyi és 15 megyei önkormányzati tag); a 13 tagú Végrehajtó Bizottságot (a folyamatos müködóképességet 7 helyettes képviseló biztosította); és egy 7 fös Munkabizottságot, ami a folyamatos operatív tevékenység ellátásáért felelös.

Elsősorban az öt év tapasztalata eredményezte a szervezeti változást, melynek során 2002-töl kétszintüvé vált a Regionális Tanács, a Közgyülés megszünt, ennek következtében a Végrehajtó Tanács funkciói és létszáma is kibövült, ez utóbbi 33 tagúvá a közgyülesi $2 / 3-1 / 3$ szellemében ( 22 helyi és 11 megyei önkormányzati képviselő). E változás legföbb oka az ülésezés hatékonysági problémája volt a 45 tagú Közgyülés esetében, melynek szerepe az évenkénti egyszeri ülésezés miatt formálissá vált. Másrészt a Végrehajtó Bizottság növekvő szerepköre miatt annak ülésszáma is emelkedett (az évi 6-ról 9-re), így téve hatékonyabbá múködését.

E szerkezetben a Végrehajtó Tanács lett az indirekt úton választott Közgyưlési testület, melynek hatásköre a Végrehajtó Bizottság által elkészített javaslatok elfogadására terjedt ki, a Regionális Tanács döntéshozatali testületévé vált. A Végrehajtó Bizottság pedig az operatív müködésért, a Tanács elé kerülỏ javaslatok elökészí- 
téséért, illetve a döntések végrehajtásáért lett felelős. Megszünt az egyes közti szintek közötti távolság, így egy még hatékonyabb szerkezet alakult ki.

A Regionális Végrehajtó Tanács tagjainak közvetett választása során figyelemre méltó a kisebbségvédelmi szabályozás. Ez biztosítja, hogy a testületekben a minden önkormányzat által delegált legalább egy tag elvén túl, minden politikai erơnek legalább egy képviselője legyen. Erre példa a 2002-es választás, melynek során az 1-2 képviselöt delegáló helyi önkormányzatokból nem került volna be egyenes ágon a választási eredmények alapján a Miljöpartiet-et (Zöldpárt) képviselö politikus, de a minél szélesebb körü regionális együttmüködés érdekében a győztes pártok, a Sozialdemokratarna (Szociáldemokrata Párt) és a Moderata (Konzervatív Párt) képviselői képviseleti lehetôséget biztosítottak a harmadik párt számára is. Ezt a felek automatikusan ajánlották fel a Miljöpartiet számára, bár törvényileg is kötelező.

Ez a kormányrendeletben lefektetett politikai struktúra kiegészül egy ún. regionális együttmüködési struktúrával, melynek feladatát a tradicionális területi szervezetekkel, helyi önkormányzatokkal való kapcsolattartás, workshopok, konferenciák szervezése képezi. Emellett magában foglalja a Kereskedelmi és Ipari Tanácsot, amely a Regionális Tanács Végrehajtó Bizottságának igazgatója és a regionális jelentőségủ gazdasági társaságok vezetői közötti informális találkozó a „üzleti élet felé nyitott ajtó" elvének szellemében. A kerekasztal-beszélgetések célja a regionális szektorális együttmúködés erösítése, Kalmar esetében különösen a stratégiai jelentőségü üveg- és faipar terén.

\section{A Tanács feladatai}

Az 1997-es Pilot Project törvényi szabályozása alapvetö feladatként a megye (lan) hosszú távú fejlesztési programjának az elkészítését írta elö a Regionális Tanács számára. A program idejére azonban más feladatátadásokra is sor került a következő önkormányzati és állami testületektől:

1) Állami

a) Megyei közigazgatási hivataloktól:

- fejlesztési támogatásokról való döntés és kifizetés

- vidékfejlesztési támogatásról való döntés és kifizetés

- projektek kidolgozása és megvalósítása

- kisvállalkozók támogatása

- EU támogatások kezelése

- megyei tömegközlekedési támogatások tervezése

b) Kulturális Ügyek Nemzeti Tanácsától:

- kormányzati támogatások elosztása helyi kulturális intézményeknek

2) Önkormányzati

a) Megyei önkormányzattól:

- megyei kereskedelem és ipar anyagi támogatása

- megyei kulturális tevékenységek finanszírozása

- középiskolai oktatás müködtetése 
- megyei környezetvédelmi tevékenység koordinálása

- nemzetközi projektek kidolgozása és megvalósítása

b) Helyi önkormányzatoktól és azok Szövetségétől a regionális érdekủ tevékenységeket koordinálja és biztosítja a

- nemzetközi kapcsolatok

- megyei turizmus

- képességek és tudás fejlesztése

- kommunikáció

- marketing és külső ellenörzés

- környezetvédelem

- kultúra

- munkaügy

- kereskedelem és ipar

- tömegközlekedési rendszerek területén.

\section{A Tanács feladatainak pénzügyi háttere}

Mielőtt elemeznénk a Kalmari Regionális Tanács pénzügyi kérdéseit, szükséges a svéd és magyar területi, helyi önkormányzati rendszer gyors összevetése bevételi és kiadási oldalon egy aránt. Elsőként nézzük a kiadásokat 1998-ban (3. táblázat):

\section{TÁBLÁZAT}

A svéd helyi és területi önkormányzati kiadások megoszlása

(The Distribution of the Local and Regional Government Expenses in Sweden)

\begin{tabular}{lrrrrrr}
\hline & \multicolumn{2}{c}{ Helyi } & \multicolumn{2}{c}{ Területi } & \multicolumn{2}{c}{ Összesen } \\
\cline { 2 - 7 } & SKR & \multicolumn{1}{c}{$\%$} & SKR & $\%$ & SKR & \multicolumn{1}{c}{ Mrd } \\
\hline Oktatás és kultúra & 95,6 & 22,1 & 4,4 & 1,0 & 100 & 23,1 \\
Rokkantak támogatása & 83,3 & 19,3 & 0,3 & 0,1 & 83,6 & 19,4 \\
Szociális szolgáltatások & 24,0 & 5,6 & 0,4 & 0,1 & 24,4 & 5,6 \\
Gyereknevelés & 39,5 & 9,1 & 0,0 & 0,0 & 39,5 & 9,1 \\
Orvosi ellátás & 10,2 & 2,3 & 93,4 & 21,6 & 103,6 & 24,0 \\
Fogorvosi ellátás & 0,0 & 0,0 & 3,3 & 0,8 & 3,3 & 0,8 \\
Oktatási, egészségügyi & & & & & & \\
és szociális kiadások & 252,6 & 58,5 & 101,8 & 23,6 & 354,4 & 82,0 \\
összesen & & & & & & \\
Infrastruktúra & 24,2 & 5,6 & 4,6 & 1,1 & 28,8 & 6,7 \\
Szórakozás & 8,8 & 2,0 & 0,0 & 0,0 & 8,8 & 2,0 \\
Üzlet & 20,8 & 4,8 & 0,0 & 0,0 & 20,8 & 4,8 \\
Adminisztráció & 4,0 & 0,9 & 3,3 & 0,8 & 7,3 & 1,7 \\
Egyéb & 9,2 & 2,1 & 2,7 & 0,6 & 11,9 & 4,4 \\
\hline Összesen & 319,6 & 74,0 & 112,4 & 26,0 & 432 & 100,0 \\
\hline
\end{tabular}

Forrás: Regional and Local ... 2001, 222. oldal 2. és 3. tábla alapján. 
Az egészhez viszonyítva látható, hogy az oktatási, egészségügyi és szociális kiadások teszik ki a területi és helyi önkormányzati kiadások többségét, annak 82\%-át. A területi és helyi szintü önkormányzati kiadásokban látható az infrastrukturális és üzleti kiadások alacsony aránya, a struktúrában egyértelmủen az önkormányzatok szolgáltató jellege dominál.

Most nézzük meg azt, hogy a kiadásokat milyen forrásokkal finanszírozzák (4. táblázat).

\section{TÁBLÁZAT}

Az önkormányzati bevételek Svédországban és Magyarországon, 1999

(The Incomes of Local Governments in Sweden and Hungary, 1999)

\begin{tabular}{cccc}
\hline Ország & \multicolumn{2}{c}{ Svédország } & Magyarország \\
\hline \multirow{2}{*}{ Az összes százalékában } & Helyi & Megyei & $\begin{array}{c}\text { Helyi és megyei } \\
\text { összevontan }\end{array}$ \\
\hline Adók & 56 & 69 & 20 \\
Díjak & 11 & 8 & 13,3 \\
Általános támogatások & 16 & 7 & 24,6 \\
Speciális támogatások & 5 & 13 & 10,1 \\
Egyéb & 12 & 3 & 32 \\
\hline Összesen & $I 00$ & 100 & $I 00$ \\
\hline
\end{tabular}

Forrás: Regional and Local ... 2001, 224.; Pénzügytan 1999, 227.

Az összehasonlító táblában látható, hogy a svéd bevételek területi nagyságtól függetlenül az adóbevételekre építenek, mintegy 2/3-os arányban. Ez jól mutatja a magyar állami támogatásalapú gazdálkodással szembeni ellentétet.

Mindezeket a svéd modell megértése érdekében kívántam bemutatni, mert a területi közigazgatás hasonlóságával szemben a pénzügyi háttér alapvetöen eltér nemcsak a büdzsé nagyságát, de arányait tekintve is Svédország és Magyarország között.

Az 1997-es kísérletek során a pénzügyi háttér az átvett feladatokkal együtt érkezett az újonnan felállított regionális intézményekhez. Kalmar esetében ez azt jelentette, hogy a fent felsorolt feladatok ellátásához szükséges minden koronát megkaptak, tehát a megyei közigazgatási hivatalok, a lansstyrrelsenék által kezelt területfejlesztési, a természeti és kulturális örökséghez kötődő európai uniós és állami támogatási forrásokat egyaránt (kivéve az agrártámogatásokat). A nehézséget az jelentette, hogy Skane és Vastergotland szupermegyés kísérlete esetén a megyék egyesítésére került sor az új regionális testület létrehozásával. Ez a testület pedig a jogelöd megyei testületek adóbevételeivel is rendelkezett, bár aránya az állami területi hivataloktól átvett területfejlesztési feladatok forrásai miatt némileg lecsökkent.

A Kalmar régióban azonban csak a területfejlesztéshez kötődö feladatok és azok pénzügyi forrásai - támogatás formájában - kerültek át a Regionális Tanácshoz, az adóbevételek megmaradtak a párhuzamosan fennmaradó megyei önkormányzatoknál az egészségügyi és oktatási feladatok ellátására. Így a Regionális Tanács működési költségeinek nem volt meg a fedezete. Ahhoz, hogy valódi munka folyjon, a Regionális Tanács az önkormányzati tagjainak adóbe vételeiből részesedésre szorult. Ezt a helyi demokratikus megoldás áraként értelmezett többletköltségnek tekinthetjük. 


\section{A modell jövóje}

2002 őszén Svédországban parlamenti és önkormányzati választásokat rendeztek. Ennek során újabb modell bevezetésére, illetve a meglévő modellek más megyékben való bevezetésére nem került sor.

Azonban a Pilot Projectek lezárult első választási ciklusai azt mutatják, hogy a kormány a jövöben a megye-régió modell bevezetését fogja támogatni.

A szupermegyés kisérletek ugyanis elsósorban a régió vezetése és az állampolgárok közti távolságot növelték meg, és demokratikus deficitet teremtettek. A regionális választások identitásteremtése kevésnek bizonyult a szupermegyék esetén, melynek legfőbb oka, hogy e kísérlet keretében a szolgáltatás-orientált regionális önkormányzatban ellátási problémák merültek fel elsősorban az egészségügyi szolgáltatások területén. Ezt az sem tudta enyhíteni, hogy a regionális igazgatást nem egy városra összpontosították, hanem megosztották az egykori megyeszékhelyek között.

A megye-régió modellben viszont a múködési költség fedezetének hiányosságain túl csak a rendszer előnyeit figyelhetjük meg. A hangsúlyt kapó területfejlesztés, a meginduló stratégiaalkotás, az együttmủködési formák sokszínủ alkalmazása, a sokféle fejlesztési forrás egy intézményben való egyesítése mind azok az elemek, amelyek kulcsfontosságúvá tették a Regionális Tanács intézményét a megváltozott európai gazdasági környezetben - csakúgy mint évszázadokkal ezelött kulcsfontosságú volt Kalmar erődje stratégiai szempontokból.

Ennek eredményeként a kormány e tapasztalatokra építve a megye-régió modellre való áttérést ösztönzi a regionalizmus intézményi reformjai során. Elsősorban a szomszédos megyék, így elsősorban Blekinge, de Kronoberg és Jönköping lan is (bár ez utóbbi megyében 2004-nél hamarabbi bevezetésről a tárgyalások elhúzódása miatt nem lehet szó) fontolgatja a megye-régió modell bevezetését. A legfőbb gátló tényező nem a modell sikerességében való kételkedés, hanem a kormányzattal folytatott, az új belépők Regionális Tanácsának pénzügyi helyzetérỏl szóló vita, illetve az időfaktor.

1) A legfőbb vitapont a Kalmar kapcsán említett területfejlesztési pénzeszközök Regionális Tanács által való szabad felhasználhatóságát kívánja gátolni. Jelenleg a megyei közigazgatási hivatalok, a lansstyrrelsenék kezelik a területfejlesztéshez, az agrártámogatásokhoz, a természeti és kulturális örökséghez kötődő európai uniós és állami támogatási forrásokat a klasszikus megyékben. A tervek szerint azonban a területfejlesztési pénzeszközök a Regionális Tanácsok megalakulása esetén is teljesen, vagy legalább 50 százalékban a lansstyrrelsenéknál maradnának. Így azonban megszünne a modell sikerességét biztosító egyik tényező, a Regionális Tanács pénzügyi függetlensége, ezzel pedig szerepük a stratégiaalkotásra szükülne le a lansstyrrelsenéval szemben.

2) Egy másik tényező az időfaktor. Svédország EU-n belüli relatív fejlettsége miatt 2007-tỏl a déli területein elveszti jogosultságát a 2. célcsoporthoz kötődő támogatásokra. Ebből adódóan a jelenlegi területfejlesztési források, me- 
lyek kezelése a Regionális Tanács egyik fö feladata, erőteljesen lecsökkennek. Így jelenleg a modell bevezetésére legfelkészültebb Blekingében a legföbb belső probléma, hogy 3-4 éves időszak állna rendelkezésre a jelenlegi keretek között a Regionális Tanács müködtetésére. Ezalatt az idő alatt - a szakemberek véleménye szerint - nem lehetséges egy olyan rugalmas szervezet kialakítása, ami a 2. célcsoport megszünését követően képes lenne más jellegü EU források programjainak kidolgozására és elnyerésére a további müködés pénzügyi fedezetének biztosítása érdekében. Ezen új források nélkül pedig indokolatlan e szerv létezése az egészségügy és oktatás pénzügyi fedezetével bíró megyei önkormányzattal és az agrártámogatásokkal bíró megyei közigazgatási hivatalokkal szemben. Ezt Kalmarban az öt évvel régebbi múltjukkal próbálják ellensúlyozni, és a forrásszerkezet átalakításának nehézségei során bíznak a tapasztalataikban.

\section{A megye-régió modell alkalmazási lehetöségei Magyarországon}

A jelenlegi magyar szerkezet a területfejlesztési feladatokat a megyei önkormányzatokhoz csatolt területfejlesztési tanácsokon keresztül látja el megyei és azok társulásaiként regionális szinten. A megye-régió modell elemzése miatt ezúttal csak az elöbbire koncentrálok.

A magyar területfejlesztési tanácsok rendszere szintén csak a területfejlesztési feladatok önálló kezelését emeli ki az önkormányzati feladatkörökböl, amihez a megyei elnök személyén keresztül kapcsolódik. Így a kalmari modellel szemben mint a megyei önkormányzat által létrehozott szerv jelenik meg, hiányzik a helyi önkormányzati felhatalmazás.

Ebböl adódik, hogy míg a megye-régió modell egy esernyőszervként müködik az érdekelt önkormányzatok felett, addig az MTT-k megyei önkormányzathoz kötötten. A svéd modell így jobban kifejezésre juttatja e területfejlesztésre koncentráló szerv koordinációs szerepkörét.

Miért lenne célszerủ Magyarországon e rendszert követni?

1) Alapvetően azért, mert az Európai Unió szabad döntési lehetőséget biztosít a tagállamok számára a területfejlesztési és a területi önkormányzati struktúra tekintetében, nincsenek kötöttségek a statisztikai NUTS rendszerhez való illeszkedést illetỏen, ami Magyarországon sokszor félreértelmezett.

2) Másodsorban a magyar megyerendszer hagyományai és szolgáltató jellege nem teszik lehetővé egy magasabb szintủ regionális identitás kialakulását, ami a svéd kísérletek során is kulcskérdésnek mutatkozott az eredményesség tekintetében.

3) Harmadsorban a megyei szintü érdekek egyesítését tovább nehezíti az erőteljesen felszabdalt helyi önkormányzati struktúra, melynek reformja Svédországban már 45 évvel (!) a regionális kísérletek elött megindult. 
4) Negyedsorban egy új regionális szint bevezetése a megyék felett olyan magas átszervezési, intézményfejlesztési költséggel járna, ami megkérdöjelezné a sokszor hangoztatott hatékonyság elvét.

5) És végül, de nem utolsósorban az egy ország - egy régió elv alkalmazása lehetővé teszi nemcsak 2006-ig, hanem a továbbiakban is (aminek sikerét Írország példája is mutatja) a 19 osztatú megyestruktúra fenntartását, és a hagyományos megyei keretek hatékonyabbá tételét, területfejlesztési feladatokkal való kiegészítését.

\section{Jegyzetek}

${ }^{1}$ E fejezet Kayfetz és szerzötársai: Swedish Local Government (1993, 7-13) alapján készült.

${ }^{2}$ Az Európai Unió régióbeosztásáról lásd E.B. 2001, 34.

3 Lansstylreselna Förbundet (A Svéd Területi Hivatalok Szövetsége): http://www.lst.se/ english/index.html

\section{Irodalom}

Bende-Szabó G. (2001) Svédország és a regionalizmus. - Magyar Közigazgatás. 2. 648-654. o. Regional und Local Democracy in the European Union (1999) Commitee of the Regions, Brusszel. Regional and Local Government in the European Union (2001) Commitee of the Regions, Brüsszel. E. B. (2001) Az Európai Unió régióbeosztásáról. - Comitatus. 3. 33-38. o.

Gren, J. (1999) The New Regionalism in the EU - The Lessons to be Drawn from Catalonia, RhoneAlpes and West Sweden. Östersund, The Swedish Institute for Regional Research [Statens institut för regionalforskning] (SIR), Fritze, Stockholm.

Hajdú Z. (2001) Magyarország közigazgatási földrajza. Dialóg Campus, Budapest-Pécs.

Jerneck, M.-Gidlund, J. (2002) Region Building, Democracy and Changing Policy-Styles in Sweden. Gustafsson, G.-Richardson, J. (eds.) Swedish Governance under Pressure. Edward Elgar, Cheltenham. Megjelenés előtti kézirat!

Kayfetz, V.-Haggroth, S.-Kronvall, K.-Riberdahl, K.-Rudebeck, K. (1993) Swedish Local Government. Swedish Institute, Falköping.

Leijon, S.-Jensen, C. (1996) Theorizing and Conceptualizing Regions: The West-Sweden Region - An Idea Searching for a (Re)form. - Alden, J.-Boland, P. (eds.) Regional Development Strategies A European Perspective. Regional Studies Association, London. 14-37. o.

Östhol, A.-Svensson, B. (2002) Swedish Cases - Partnerships by State-Led Design. - Östhol, A.Svensson, B. (eds.) Partnership Responses - Regional Governance in the Nordic states. Future Challenges and Institutional Preconditions for Regional Development Policy (Volume 4), Nordregio Report, Oslo. 85-134. o.

The Regional Council for the County of Kalmar (1997) The Road to Development for the County of Kalmar. Landstinget i Kalmar Lan - Kommunförbundet Kalmar Lan, Kalmar. 